\title{
Forest Logging and It Impact on Soil Carbon Dioxide Effluxin the tropical Forest, Peninsular Malaysia
}

\author{
Mande, Kato. Hosea ${ }^{1}$,Abdullah Ahmad Makmom ${ }^{2}$.,Aris, Ahmad Zaharin ${ }^{3}$., \\ Ainuddin, Ahmad Nuruddin ${ }^{4}$ Binyemed, FadelMohamed ${ }^{1}$., Ben Youssef, \\ Khaleed Ali Ahmed ${ }^{1}$. \\ ${ }^{1}$ Air Pollution \&Ecophysiology Laboratory, Department of Environmental Planning \& Management, Faculty of \\ Environmental Studies, Universiti Putra Malaysia, 43400 UPM Serdang, Selangor, Malaysia. \\ ${ }^{2}$ Department of Environmental Sciences, Faculty of Environmental Studies, Universiti Putra Malaysia, 43400 \\ UPM Serdang, Selangor DarulEhsan, Malaysia. \\ ${ }^{3}$ Environmental Forensics Research Centre, Faculty of Environmental Studies, Universiti Putra Malaysia, \\ 43400 UPM Serdang, Selangor DarulEhsan, Malaysia. \\ ${ }^{4}$ Institute of Tropical Forest and Forest Product University Putra Malaysia 43400 UPM, Serdang, , Selangor \\ DarulEhsan, Malaysia.
}

Corresponding author: Ahmad Makmom Abdullah, Department of Environmental Sciences, Faculty of Environmental Studies, Universiti Putra Malaysia, 43400 UPM Serdang Selangor, Malaysia. amakmom@upm.edu.my Office: +60389466733. Mobile phone: +601126250360, Fax 03-89438109

\begin{abstract}
Forest harvesting is expected to have an impact on soil $\mathrm{CO}_{2}$ efflux as it influence soil properties and changesinmicroclimatic conditions which can have implications on the regional carbon balance. Soil $\mathrm{CO}_{2}$ efflux was measured using a continuous open flow chambers technique connected to a multi-gas-handling unit and infrared $\mathrm{CO}_{2} / \mathrm{H}_{2} \mathrm{O}$ gas analyser. Soil temperature, soil moisture, water potential, Total Organic Carbon (TOC), Soil Organic Carbon (SOC), Soil Organic Carbon stock (SOCstock), Bulk density and pH were examinedto ascertain their contribution onsoil $\mathrm{CO}_{2}$ efflux and effect ofenvironmental factors in a canopy gap created through the logging of groups of trees in the Sungai Menyala forest, Peninsular Malaysia. The aim was to determine soil $\mathrm{CO}_{2}$ efflux and the change in soil properties resulting from deforestation. Multiple regression shows a strong relationship $\left(r^{2}=0.949 ; p<0.01\right)$ between the soil $\mathrm{CO}_{2}$ efflux and soil properties resultedfrom deforestation. SoilCO $\mathrm{O}_{2}$ efflux ranged from 143.14 to $364.17,103.26$ to $404.81,111.17$ to $466.78,234.72$ to 445.03 and 277.25 to $475.3 \mathrm{mg} \mathrm{m}^{-2} h^{-1}$ from February to June 2013, respectively, and varies withtime present in the higher soil temperature and the amount of TOC, SOC, SOCstock. We found that soil $\mathrm{CO}_{2}$ efflux in loggedover land was much higher compared to that in the recovering and primary forest. Soil temperature was found to have a strong effect on the increase in soil $\mathrm{CO}_{2}$ efflux; similarly, the change in soil properties was found to have a positive effect. The resultssuggested that forest harvest has a strong influence on soil $\mathrm{CO}_{2}$ efflux through changes in the soil temperature and soil properties.
\end{abstract}

Keywords: Atmospheric carbon pool, Logged-over;Microbial; Organic carbon; $\mathrm{Soil} \mathrm{CO}_{2}$ efflux.

\section{Introduction}

Soil in the terrestrial ecosystem has been reported to contribute about $68-100 \mathrm{Pg}$ carbon year $^{-1}$ and 60 $80 \mathrm{Pg}$ carbon year ${ }^{-1}$ into the atmosphere, which is $30-60 \%$ greater than the terrestrial net primary productivity $[1,2]$. This magnitude of soil $\mathrm{CO}_{2}$ efflux is large enough to exacerbatetheincrease in the atmospheric $\mathrm{CO}_{2}$ with implications on climate change [3]. The driving force behind the spatial and temporal variation of soil $\mathrm{CO}_{2}$ efflux has been attributed to temperature and moisture [4], while other critical factors that are associated are water content and soil organic materials[5,6].

Forest harvesting, land conversion and disturbance have considerable implications on soil $\mathrm{CO}_{2}$ efflux, and have been reported to either increase or decrease $\mathrm{CO}_{2}$ efflux from forest soils compared to undisturbed forest $[6,7]$. The overall effect of deforestation will displace the aboveground biomass as the forest ecosystem serves as a carbon sink, and carbon assimilation via photosynthesis resultsin the efflux of $\mathrm{CO}_{2}$ into the atmospheric carbon pool [8]. Forest harvesting causes drastic and unexpected changes in the microbial activity, litter fall input, root density, production and insolation, which results in predictable changes in the $\mathrm{CO}_{2}$ efflux from forest soils. [9] reported that forest harvesting has a negative impact on the forest soil $\mathrm{CO}_{2}$ and that it has yielded various degrees of inconsistent results. Large increases and large decreases in soil $\mathrm{CO}_{2}$ efflux have been recorded in respect of the general ecological system $[5,10]$. 
The major challenge with deforestation concerns the impact of soil $\mathrm{CO}_{2}$ emission rates as it reduces the efficiency of root respiration compared to that of an undisturbed forest ecosystem, and results in the death of the root systems of the harvested trees, which reduces or eliminates the contribution of root respiration, as the root system accounts for about 50-70\% of soil respiration [11]. Forest harvesting disturbs the physiological activity of tree roots and microbial conditions, which could likely have a large impact on the soil $\mathrm{CO}_{2}$ efflux $[12,13]$. However, the $\mathrm{CO}_{2}$ efflux from the soil due to forest harvesting is quite high as a result of the decay of fine roots and increased temperature for microbial activity.In addition, this scenario could vary over time. In the tropical forest of Malaysia, studies have not being documented concerning the impact of deforestation on the soil $\mathrm{CO}_{2}$ efflux, despite several years of deforestation. Although soil $\mathrm{CO}_{2}$ fluxes are critical to fully understand the different forest management systems, there are few studies in Malaysia concerning the response of soil $\mathrm{CO}_{2}$ efflux to either partial stand harvesting or fully logged areas. This study determines the soil $\mathrm{CO}_{2}$ efflux and changes in the soil properties resulting from the effect of deforestation.

\subsection{Site description}

\section{Materials And Methods}

The study site was located in a 2 ha logged-overdipterocarpus forest of Sungai Menyala forest $\left(27^{\circ} 50^{\prime} 95^{\prime \prime} \mathrm{N} 43^{\circ} 64^{\prime} 99^{\prime \prime} \mathrm{E}\right)$,Port Dickson, Peninsular Malaysia. The forest experiences equatorial climatic condition with a monthly rainfall of $200 \mathrm{~mm}$ between October and January, with theoccurrence of light showers between February and September[14]. The area has a mean annual temperature range of $23.7-32^{\circ} \mathrm{C}$ and relative humidity of $59-96 \%[15]$, and the soil is classified as the Serdang-Kedah series developed over mixed sedimentary rocks with a combination of local alluvium colluvium resulting from metamorphic rock [16,17]. In the FAO/UNESCO Soil Map of the World - Revised Legend ,the Serdang series is classified as Haplic Nitisols [18].

\subsection{Experimental design}

The study examines soil $\mathrm{CO}_{2}$ efflux in responses to logging activities, as 50 x $50 \mathrm{~m}$ plot was demarcated in a canopy gap created as result of logging of group's trees. This was conducted in a split plot designed as the logged area and as the main plot effect while two replicates of another logged area and a nonlogged forest area. The logging was conducted in 2006 providing seven years after harvesting. The replicate stand designates a portion of a logged-block relatively homogeneous in species composition, forest structure, and the stand is of the same soil and topography. Also the replicate logged area and stand forest was sampled in spatially non-contiguous where possible with locations chosen to maximize spatial interspersion among harvest date. There were thirty measurement points at each plot location, at a space distance of $5 \mathrm{~m}$, given a total of 150 sampling points in the study ( 1 logged-over area as main plot, 2 replicates logged-over plots and 2 non-loggedover plots areas).

\subsection{Measurement of soil $\mathrm{CO}_{2}$ efflux and related environmental parameters}

Soil $\mathrm{CO}_{2}$ efflux was measured on a daily basis, from 0800 - 1700hour, from February to June, 2013 representing the tropics season. Two constructed continuous open flow chambers of $64 \mathrm{~cm}$ in height and $50 \mathrm{~cm}$ width, having a flow fan for the mixture of $\mathrm{CO}_{2}$. The chambers were connected to a multi gas-handler (WA 161 model), which provides a channel to regulate the flow of $\mathrm{CO}_{2}$ from various chambers to a flow meter connected with a $\mathrm{CO}_{2} / \mathrm{H}_{2} \mathrm{O}$ gas analyser (Li-Cor 6262)[19]. Soil $\mathrm{CO}_{2}$ efflux was recorded every $5 \mathrm{sec}$ over a period of $5 \mathrm{~min}$ in each chamber, from which an average was calculated to estimate the $\mathrm{CO}_{2}$ concentration over $5 \mathrm{~min}$ for each chamber. A standard calibration (zero setting) of $\mathrm{CO}_{2}$ and $\mathrm{H}_{2} \mathrm{O}$ was carried out using silica gel and soda lime. A $3 \mathrm{~cm}$ thick closed foam gasket was placed between the chamber base and the soil collar to prevent leakage while soil collars were randomly inserted $3 \mathrm{~cm}$ into the soil for 24 hours before commencement of measurement for soil pressure to stabilize in order to create an equilibrium stage and kept in place throughout the entire period of the study. The daily data were collected at the whole study areas with a similar weather pattern.

Soil temperature, soil moisture and water potential was measured using probes (Watchdog data logger model 125 spectrum technology, Delmorst model KS-D1 and Trime-Fm TDR), respectively at $5 \mathrm{~cm}$ below the soil surface concurrent with soil $\mathrm{CO}_{2}$ measurement. Soil samples were collected from three different locations at randomusing the soil core with a metal core sampler of $10 \mathrm{~cm}$ in diameter and $10 \mathrm{~cm}$ in height at a depth of 0 $100 \mathrm{~cm}$. The volume of the core sampler was determined using the equation one (1). The sample was preserved with the metal cylinder core in an airtight plastic bag and taken to the laboratory for determination of $\mathrm{pH}$ using a glass electrode in a saturated soil water paste, Total Organic Carbon (TOC), Soil Organic Carbon (SOC) and soil moisture content using the Walkley-Black standard method with a correction factor of 1.33 in related to Sollins et al. (1999), as it is appropriate for moisture analyses because of its simplicity. The carbon and nitrogen ratioswere determined from the replicate forest stand based on equations two to nine (2-9).

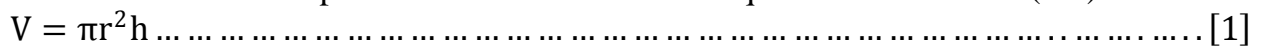


Where; $\mathrm{V}=$ volume $\left(\mathrm{cm}^{3}\right), \mathrm{r}=$ the radius of the core sampler $(\mathrm{cm})$ and $\mathrm{h}$ is the height of the core sampler $(\mathrm{cm})$. The soil samples were weight, air dry and oven dry at $105^{\circ} \mathrm{C}$ for 48 hours.

The earth bulk density, which indirectly provides a measure of the soil porosity (pore spaces), was determined using the standard method of soil analysis (Nhantumbo and Bennie 2001).

$$
\text { Bulkdensity }\left(\mathrm{Mgm}^{-3}\right)=\mathrm{g} / \mathrm{v}
$$

Where; $\mathrm{g}=$ oven dry mass of the sieve soil $(\mathrm{g}), \mathrm{V}=$ sample volume $\left(\mathrm{cm}^{-3}\right)$.

The soil moisture content was determined in accordance with the standard method based on the following equation:

$$
\begin{array}{r}
\text { Moisturecontentinwt } \%(\mathrm{w} / \mathrm{w}) \text { isobtainedby : } \\
\text { Moist }(\mathrm{wt} \%)=\left[\frac{(\mathrm{A}-\mathrm{B})}{(\mathrm{B}-\text { taretin })}\right] \times 100 \ldots \ldots \ldots \ldots \ldots \ldots \ldots \ldots \ldots \ldots \ldots \ldots \ldots \ldots \ldots \ldots
\end{array}
$$

The corresponding moisture correction factor (mcf) for analytical results is:

Moisturecorrectionfactor $=(100+\%$ moist $) / 100$.

Where, A=air dry soil, $\mathrm{B}=$ oven dry soil.

The Total Organic Carbon (TOC) was determined by the Walkley-Black method using a correction factor of $1.33[20]$, as it is appropriate for moisture analyses because of its simplicity;

Where:

$$
\operatorname{Toc}(\% \mathrm{M})=\mathrm{Mx}[(\mathrm{V} 1-\mathrm{V} 2) / \mathrm{S}] \times \mathbf{x} 0.39 \operatorname{xmcf} \ldots \ldots \ldots \ldots \ldots \ldots \ldots \ldots \ldots
$$

$\mathrm{M}=$ molarities of ferrous sulphate solution (from blank titration)

$\mathrm{V} 1 \mathrm{ml}$ ferrous sulphate solution required for blank

$\mathrm{V} 2 \mathrm{ml}$ ferrous sulphate solution required for $\mathrm{S}=$ weight of air dry sample in grams

$\mathrm{mcf}=3$ (equivalent weight of carbon) corrected factor.

Soil Organic Carbon (SOC) was determined using the following equation:

$$
\mathrm{M}=10 /
$$

$$
\begin{aligned}
& \text { \%oxidizableorganiccarbon }(\mathrm{w} / \mathrm{w})=\left[\text { Vblank }- \text { Vsample] } / \mathrm{Wt}_{\mathrm{t}} \times 0.3 \mathrm{xmass} \ldots \ldots\right. \text {... [6] } \\
& \text { \%totalorganiccarbon }(\mathrm{w} / \mathrm{w})=1.334 \mathrm{x} \% \text { oxidazableorganiccarbon ............ [7] } \\
& \text { \%organicmatter }(\mathrm{W} / \mathrm{w})=1.724 \mathrm{x} \% \text { totalorganiccarbon } \ldots \ldots \ldots \ldots \ldots \ldots \ldots \ldots[\mathrm{\ldots} \ldots \ldots \ldots
\end{aligned}
$$

Where:

$\mathrm{M}=$ molarities of ferrous ammonium sulphate solution (app $0.5 \mathrm{~cm}^{-3}$ )

$\mathrm{V}$ blank = volume of ferrous ammonium sulphate solution required to titrate the blank $\left(\mathrm{cm}^{-3}\right)$

$=$ Volume of ferrous ammonium sulphate solution required to titrate the sample $\left(\mathrm{cm}^{-3}\right)$

$\mathrm{wt}=$ weight of air dry soil $(\mathrm{g})$

$0.3=3 \times 10^{-3} \times 100$ where 3 is the equivalent weight of $\mathrm{C}$

The Soil Organic Carbon Stock was ascertained to verify the amount of the stock of carbon held in a given area of the soil, taking cognisance of the compaction and depth of the soil while the earth bulk density had to be determined. The soil depth recommended for the stock of carbon assessment is the top $100 \mathrm{~cm}$ [21]. The Soil Organic Carbon Stock held in a given area of soil can then be expressed as:

Where:

$$
\mathrm{SOC}_{\text {stock }}=\left[\frac{\text { SOCcontentofsoil } \times \mathrm{BD} \times \text { area } \times \text { depth }}{10}\right]
$$

SOC $=$ Soil Organic Carbon

$\mathrm{BD}=$ Bulk Density

Depth= Depth of the soil.

Soil $\mathrm{pH}$ and Electric conductivity was determined.

\section{Statistical Analysis}

Statistical tests for the effect of loggingand its interaction with soil moisture, temperatureand changes soil properties on soil $\mathrm{CO}_{2}$ efflux were performed using a parametric one-way ANOVA, followed by a post hoc Dunn's test and Turkey multiple comparison test. The analysis of variance (ANOVA) was used to test the difference of standard deviation and mean soil $\mathrm{CO}_{2}$ efflux. No transformation of soil $\mathrm{CO}_{2}$ data, soil temperature and moisture data was conducted as they satisfied the normality and homoscedasticity assumptions of ANOVA. In addition, descriptive statistics were established to calculate and explain the normality of data distribution and to quantify the relationship between the soil $\mathrm{CO}_{2}$ and the environmental factors. Multiple linear regression 
analysis was employed to ascertain the confounding significant effect of logging, environmental factors and soil properties on soil $\mathrm{CO}_{2}$ efflux, with the best-fit model chosen using Akaike's Information Criterion (AIC). Likewise, Pearson correlation was calculated to show the correlation of the $\mathrm{CO}_{2}$ efflux variation with the environmental factors.

\section{Results And Discussion}

Soil $\mathrm{CO}_{2}$ efflux was recorded to rangefrom 143.14 to $364.17,103.26$ to $404.81,111.17$ to 466.78 , 234.72 to 445.03 and 277.25 to $475.3 \mathrm{mg} \mathrm{m}^{-2} \mathrm{~h}^{-1}$ in the February, March, April, May and June, respectively, with an average efflux rate of $103.26-475.37 \mathrm{mg} \mathrm{m}^{-2} \mathrm{~h}^{-1}$ (Table 1). Soil $\mathrm{CO}_{2}$ efflux increase from February and reached a maximum in June (Fig. 1) similar to previous reports [22,23,24] with the minimum at $0800 \mathrm{hrs}$ and attending the peak between $1300 \mathrm{hrs}$ and $1400 \mathrm{hrs}$. The efflux trend scenario coincided with the end of the monsoon regime by February and the resumption of the post monsoon in March with its peak in June. The reason behind the maximum soil $\mathrm{CO}_{2}$ efflux in June may be attributed to the relatively high soil temperature [23]. A positive correlation $(\mathrm{p}<0.001)$ with the corresponding environmental factors of soil temperature, soil moisture and water potent occurred at $24.54-25.66^{\circ} \mathrm{C}, 21.43-26.25 \%$ (Fig. 2) and $94.1-96.8 \%$, respectively. The multiple linear regression model provided the best fit for describing the relationship between soil $\mathrm{CO}_{2}$ efflux and soil temperature, soil moisture and water potential $r^{2}=0.816$ to $0.948 p<0.001$ (Table 2). Furthermore, the beta coefficient from the multiple regression indicated that the soil temperature, soil moisture and water potential were responsible for the soil $\mathrm{CO}_{2}$ efflux with a beta coefficient of $0.447,0.204$ and 0.561 , respectively, in February (Table 3). Furthermore, in March, the soil temperature was a leading factor for $\mathrm{CO}_{2}$ efflux with the soil moisture at a beta coefficient of 0.904 and water potential at constant or low level of occurrence at a beta coefficient of -1.089 and -0.116 , respectively (Table 4). The soil temperature and water potential significantly influenced the soil $\mathrm{CO}_{2}$ efflux in April with a beta coefficient of 0.546 and0 .985, respectively, with low impact of soil moisture at -0.381 (Table 5). Similarly, in May, the soil temperature and water potential were very responsible for the soil $\mathrm{CO}_{2}$ efflux with a beta coefficient of 0.077 and 0.492 ,respectively, which was greater than the soil moisture at -0.513 (Table 6). A similar trend was also recorded in the month of June, the peak of the post monsoon, in which it was observed that the soil temperature and water potential were the major factors for soil $\mathrm{CO}_{2}$ efflux with a beta coefficient at 0.608 and 0.018 ,respectively, while the soil moisture had less impact at -0.497 (Table 7). The overall role of the environmental factors on soil $\mathrm{CO}_{2}$ efflux was found to be strong and significantly positively related.

Table 1: Descriptive statistics of soil $\mathrm{CO}_{2}$ efflux $\left(\mathrm{mg} \mathrm{m}^{-2} \mathrm{~h}^{-1}\right)$

Table 2: The best single and multiple-regression models were generated using enter independent variable selection

Table 3: Logged-over area estimates of the coefficient of the model of environmental parameters in ${ }^{\circ} \mathrm{Cand} \%$ for soiltemperature, soil moisture and water potential in February.

Table 4: Logged-over area estimates of the coefficient of the model of environmental parameters in ${ }^{\circ} \mathrm{Cand} \%$ forsoil temperature, soil moisture and water potential in March.

Table 5: Logged-over area estimates of the coefficient of the model of environmental parameters in ${ }^{\circ} \mathrm{Cand} \%$ forsoil temperature, soil moisture and water potential in April.

Table 6: Logged-over area estimates of the coefficient of the model of environmental parameters in ${ }^{\circ} \mathrm{Cand} \%$ forsoil temperature, soil moisture and water potential in May.

Table 7: Logged-over area estimates of the coefficient of the model of environmental parameters in ${ }^{\circ} \mathrm{Cand} \%$ for soil temperature, soil moisture and water potential in June.

Fig. 1.Soil $\mathrm{CO}_{2}$ efflux trend across five months

Fig. 2. Average Soil temperature and moisture across five months

The physiochemical parameters recorded from the soil sample analysis showed considerable percentages of Total Organic Carbon (TOC), Soil Organic Carbon (SOC), soil moisture content, moisture correction factor and Soil Organic Carbon stock (SOCstock), as 2.12\%, 1.4\%, 15.47\%, 1.15\% and 23.32 Mgha ${ }^{-1}$, respectively, while the $\mathrm{pH}$ was 5.75 - slightly acidic soil, (Table 8 ). The bulk density was recorded to increase 
from thedepthof 0 to $100 \mathrm{~cm}$ (Fig 3), giving good porosity for water movement, electric conductivity, and cation exchangecapacityto hold onto soil nutrients suitable for microbialactivity.

Using statistical analysis to test for the relationship between the soil $\mathrm{CO}_{2}$ efflux and environmental factors, one way ANOVA analysis revealed good significant differences in the soil $\mathrm{CO}_{2}$ efflux across the months of measurement with a significant level at $\mathrm{p}<0.001$. The post Hoc Test (Tukey/Scheff/Bonferroni) indicated a significant difference at $\mathrm{p}<0.001$ level. The normal Q-Q plot of distribution showed that all the observed values for the various months fall along a straight line, and the box plot showed no outlier data, giving a good distribution of data with skewness (Fig. 4). The average soil $\mathrm{CO}_{2}$ efflux was observed to range from 103.26-475.37 $\mathrm{mg} \mathrm{m}^{-2} \mathrm{~h}^{-1}$ similar to the open field under a semi-arid climate in China [25], and relatively higher than the onion field in Japan, 11-307 $\mathrm{mg} \mathrm{m}^{-2} \mathrm{~h}^{-1}$ (Hul et al. 2003). Comparing the soil $\mathrm{CO}_{2}$ efflux in the loggedover area and the standing forest showed that the logged-over area was observed to have higher soil respiration comparedto the deciduous forest of Japan [27], the Pasoh forest of lowland Peninsular Malaysia [28], the 39year old larch stand in Korea, [29] and the forest of Hokkaido, Japan [30]. This result indicated that the forest logging area has a higher soil $\mathrm{CO}_{2}$ efflux, which suggests that logging has a significant long-term effect on $\mathrm{CO}_{2}$ emissions. In order to relate the effect of $\mathrm{CO}_{2}$ emissions to environmental factors - soil temperature, soil moisture, water potential, TOC, SOC, SOCstock, bulk density and $\mathrm{pH}$ - the multiple linear regression model was employed. The classical assumption for linear regression comprises the check and collinearity diagnostic, which showed that none of the conditional index models for the logged area data was above the threshold limit of 30.0. In addition, none of the tolerance values were less than 0.10 indicating no multicollinearity problem among the variables of the models. With this condition met, it is reasonable to conclude that the estimated multiple linear regression model can be used to explain the impact of environmental factors on soil $\mathrm{CO}_{2}$ efflux. Given thatthe increase in soil $\mathrm{CO}_{2}$ was strongly associated with an increase in soil temperature over time, the availability of soil moisture, water potential, considerable amount of TOC, SOC, SOC stock [31] and soil porosity (bulk density) also enhance the pore spaces for water movement for microbial activity in slightly acidic soil. This entire process occurred due to the change in the microclimate and soil properties of the plot area resulting from deforestation, whichcaused the death and decay of the root systems and thereby further reducing their efficiency. The deforestation also caused a change in soil temperature, soil properties and an increase in microbial activities to displace the considerable amount of soil $\mathrm{CO}_{2}$ efflux.

Table 8: Analysis of soil samples

Fig. 3. Bulk Density

Fig. 4.Box and whisker plot of environmental parameters.

\section{Conclusion}

The study revealed that the soil $\mathrm{CO}_{2}$ efflux and soil temperature are parallel to the associated changes in the soil properties. The results suggested that the high carbon input fromthe forest biomass and the increaseinTotal Organic Carbon (TOC), Soil Organic Carbon (SOC), Soil Organic Carbon stock (SOCstock) and bulk densityare influenced by changes in the microclimate conditions, whichincrease the soil nutrients and microorganism activity to emit soil $\mathrm{CO}_{2}$, as was also reported by [32] and [33]. Deforestation increased the plant decay, as well as changes in the microclimate, soil properties and favourable soil $\mathrm{pH}$, whichenhanced the microbial activity and displayed a high percentage of soil $\mathrm{CO}_{2}$ directly into the atmosphere. Furthermore, the monthly variation in soil $\mathrm{CO}_{2}$ is highly attributed to the presence of relatively high soil temperature, moderate soil moisture and water potential, which are very conducive for microbial activity [34]; [35]. The observed soil $\mathrm{CO}_{2}$ efflux resulted from the logged-over area being higher compared tothevarious forest stands, therefore, we concluded that the logging of the forest might have considerable influence on the soil $\mathrm{CO}_{2}$ efflux in terms of emitting a higher amount of $\mathrm{CO}_{2}$ into the atmospheric carbon pool in respect of the future global warming scenario.

\section{Acknowledgements}

This study was supported by the University Research Grant Scheme of Universiti Putra Malaysia (Vot No.RUGS 9364800). We are grateful to the Research Management unit of the Universiti Putra, Global Carbon Cycle Research Section Japan, Center for Global Environmental Research National Institute of Environmental Studies Japan, Staff of the Faculty of Environmental Studies, Universiti Putra Malaysia, Staff of the Centre for Marine studies, Port Dickson Malaysia, Forest Department of Negeri Sembilan and forest rangers of Sungai Menyala forest. 


\section{References}

[1]. S. Akburak and E. Makineci, "Temporal changes of soil respiration under different tree species.," Environ. Monit. Assess., vol. 185, no. 4, pp. 3349-58, Apr. 2013.

[2]. "Raich, J. W., and Potter, C. S., 1995. Global patterns of carbon dioxide emissions from soils. Global Biogeochemistry Cycles 9: 23-36.," p. 1995, 1995.

[3]. J. Tang, X., Zhou, G., Liu, S., Zhang, D., Liu, S., Li, “Tang, X., Zhou, G., Liu, S., Zhang, D., Liu, S., Li, J., et al. (2006). Dependence of soil respiration on soil temperature and soil moisture in successional forests in Southern China. Journal of Integrative Plant Biology, 48(6), 654-663.," vol. 48, p. 2006, 2006.

[4]. "Billings, S.A., Richter, D.D., Yarie. J., 1998. Soil carbon dioxide fluxes and profile concentrations in two boreal forests. Can J For Res 28:1773-1783," p. 1998, 1998.

[5]. "Londo, A.J., Messina, M.G., and Schoenholtz, S.H., 1999. Forest harvesting effects on soil temperature, moisture, and respiration in a bottomland hardwood forest. Soil Science Society of America Journal 63: 637-644.,” p. 1999, 1999.

[6]. "Ewel, J., Berish, C., Brown, B., Price, N., and Raich, J., 1981. Slash and burn impacts on a Costa Rican wet forest site. Ecology 62(3): 816-829.,"vol. 62, no. 3, p. 1981, 1981.

[7]. "Toland, D.E., and Zak, D.R., 1994. Seasonal patterns of soil respiration in intact and clear-cut northern hardwood forests. Canadian Journal of Forest Research 24: 1711-1716," p. 1994, 1994.

[8]. "Striegl, R.G., and Wickland, K.P., 1998. Effects of a clear-cut harvest on soil respiration in a jack pine-lichen woodland. Canadian Journal of Forest Research 28: 534-539.," p. 1998, 1998.

[9]. 2003 Laporte, M.F., Duchesne , L.C., Morrison, I.K., "Effect of clear cutting, selection cutting, shelter wood cutting and microsites on soil surface CO2 efflux in a tolerant hardwood ecosystem of Northern Ontario. For Ecol Manage 174:565-575," p. $2003,2003$.

[10]. "Edwards, N.T., Ross-Todd, B.M., 1983. Soil carbon dynamics in a mixed deciduous forest following clear-cutting with and without residue removal. Soil Sci Soc Am J 47:1014-1021," p. 1983, 1983.

[11]. Y. Peng and S. C. Thomas, "Soil CO2 efflux in uneven-aged managed forests: temporal patterns following harvest and effects of edaphic heterogeneity," Plant Soil, vol. 289, no. 1-2, pp. 253-264, Nov. 2006.

[12]. "Hanson, P.J., Edwards, N.T., Garten, C.T., and Andrews, J.A. 2000. Separating root and soil microbial contributions to soil respiration: A review of methods and observations. Biogeochemistry 48: 115-146.," p. 2000, 2000.

[13]. "Boone, R.D., Nadelhoffer, K. J., Canary, J.D., Kaye, J.P., 1998. Roots exert a strong influence on the temperature sensitivity of soil respiration. Nature 396:570-572,” p. 1998, 1998.

[14]. J. Suhaila and A. A. Jemain, "Fitting the Statistical Distribution for Daily Rainfall in Peninsular Malaysia Based on AIC Criterion," vol. 4 , no. 12 , pp. 1846-1857, 2008.

[15]. Malaysia Meteorological Department, "Malaysia Meteorological Department(MMD)., 2013. www.met.gov.my.” 2013.

[16]. S. Paramananthan, "Malaysian Soil Taxonomy (second Approximation): A Proposal for the Classification of Malaysian Soils. Malaysian Society of Soil Science, pp 121-156," pp. 121-156, 1998.

[17]. Paramananthan S., "Keys to the Identification of Malaysian Soils using Parent Materials, 2-20," no. M, pp. 2 -20, 2012.

[18]. FAO, "(Food and Agriculture Organization of the United Nation) FAO/UNESCO Soil map of the world: revised legend 1:5,000,000 Vol. 1-10 Paris: UNESCO," vol. 1-10, 1990.

[19]. N. A. (2013) Mande, K. H., Ahmad, A. M., Ahmad, Z. A., Ahmad, "soil carbon dioxide efflux and atmospheric impact in a 10-yearold dipterocarpus recovering lowland tropical forest, peninsular Malaysia. From source to solution. Proceedings of the IENFORCE 2013. Springer Publishing: Heidelberg, New York, 165-169,” pp. 165-169, 2013.

[20]. "Sollins, P., Glassman, C., Paul, E.A., Swanston, C., Lajtha, K., Heil, J.W., Elliott, E.T., Robertson, P. G., 1999. Soil carbon and nitrogen: pools and fractions. Standard soil methods for long-term ecological research. Oxford University Press UK. 89-105." p. 1999, 1999.

[21]. "Eleanor, M., 2008. Soil organic carbon. In: Cleveland CJ (ed) Encyclopedia of earth. Environmental Information Coalition, National Council for Science and the Environment, Washington, DC. Retrieved June 13, 2009.

[22]. M. . Rayment and P. . Jarvis, "Temporal and spatial variation of soil CO2 efflux in a Canadian boreal forest," Soil Biol. Biochem., vol. 32, no. 1, pp. 35-45, Jan. 2000.

[23]. G. . Drewitt, T. . Black, Z. Nesic, E. . Humphreys, E. . Jork, R. Swanson, G. . Ethier, T. Griffis, and K. Morgenstern, "Measuring forest floor CO2 fluxes in a Douglas-fir forest," Agric. For. Meteorol., vol. 110, no. 4, pp. 299-317, Feb. 2002.

[24]. P.-L. Shi, X.-Z. Zhang, Z.-M. Zhong, and H. Ouyang, "Diurnal and seasonal variability of soil CO2 efflux in a cropland ecosystem on the Tibetan Plateau," Agric. For. Meteorol., vol. 137, no. 3-4, pp. 220-233, Apr. 2006.

[25]. H.-M. Jin, O. J. Sun, Z.-K. Luo, and J. Liu, "Dynamics of soil respiration in sparse Ulmus pumila woodland under semi-arid climate," Ecol. Res., vol. 24, no. 4, pp. 731-739, Aug. 2009.

[26]. 2003. Hul R., Hatano, R., Kusa, K., and Sawamoto, T., "Soil Respiration and Net Ecosystem Production in an Onion Field in Central Hokkaido, Japan Soil Sci. Plant Nutr., 50 (I), 27 - 33,” vol. 50, no. I, p. 2003, 2003.

[27]. M. Lee, K. Nakane, T. Nakatsubo, and H. Koizumi, "Seasonal changes in the contribution of root respiration to total soil respiration in a cool-temperate deciduous forest," Plant Soil, vol. 255, no. 1, pp. 311-318, Aug. 2003.

[28]. M. Adachi, Y. S. Bekku, W. Rashidah, T. Okuda, and H. Koizumi, "Differences in soil respiration between different tropical ecosystems,” Appl. Soil Ecol., vol. 34, no. 2-3, pp. 258-265, Dec. 2006.

[29]. C. Kim, "Carbon storage , litterfall and soil CO 2 efflux of a larch ( Larix leptolepis ) stand," no. February 2012, pp. 37-41, 2006.

[30]. R. Hu, K. Kusa, and R. Hatano, "Soil Science and Plant Nutrition Soil respiration and methane flux in adjacent forest, grassland, and cornfield soils in Hokkaido, Japan Soil Respiration and Methane Flux in Adjacent Forest, Grassland, and Cornfield Soils in Hokkaido , Japan," no. October, pp. 37-41, 2001.

[31]. Q. I. Ming, X. U., and Ye, "Soil- surface CO2 efflux and it spatial and Temporal variation in a young ponderosa pine plantation In northern California. Global Change Biology 7. 667-677.," pp. 667-677, 2001.

[32]. D. Asensio, J. C. Yuste, S. Mattana, À. Ribas, J. Llusià, and J. Peñuelas, "Litter VOCs induce changes in soil microbial biomass C and N and largely increase soil CO2 efflux," Plant Soil, vol. 360, no. 1-2, pp. 163-174, Apr. 2012.

[33]. H. K. Mande, A. M. Abdullah, A. Z. Aris, and A. N. Ainuddin, "Factors responsible for spatial and temporal variation of soil CO2 efflux in a 50 year recovering tropical forest, Peninsular Malaysia," Environ. Earth Sci., pp. DOI 10.10077/s12665-014-3810-8, Oct. 2014

[34]. "Hibbard, K. A., Law, B. E., Reichstein, M., Sulzman, J., 2005. An analysis of soil respiration across northern hemisphere temperate ecosystems. Biogeochemistry. 73, 29-70.," p. 2005, 2005.

[35]. H. K. Mande, A. M. Abdullah, A. Z. Aris, and A. A. Nuruddin, “A Comparison of Soil CO 2 Efflux Rate in Young Rubber Plantation, Oil Palm Plantation, Recovering and Primary Forest Ecosystems of Malaysia,” vol. 23, no. 5, pp. 1649-1657, 2014. 
Table 1. Descriptive statistics of soil $\mathrm{CO}_{2}$ efflux microgram $/ \mathrm{mole} / \mathrm{hour}\left(\mathrm{mg} \mathrm{m}^{-2} \mathrm{~h}^{-1}\right)$

\begin{tabular}{|c|c|c|c|c|c|c|c|c|}
\hline & $\mathrm{N}$ & Mean & Std. Deviation & Std. Error & $\begin{array}{l}\text { 95\% Confiden } \\
\text { Interval for M } \\
\text { Lower Bound }\end{array}$ & Upper Bound & Min & Max \\
\hline February & 72 & 275.5249 & 61.50806 & 7.24879 & 261.0712 & 289.9786 & 143.14 & 364.17 \\
\hline March & 72 & 272.5367 & 88.86396 & 10.47272 & 251.6547 & 293.4188 & 103.26 & 404.81 \\
\hline April & 72 & 314.8683 & 119.76305 & 14.11421 & 286.7254 & 343.0113 & 111.17 & 466.78 \\
\hline May & 72 & 358.8160 & 70.95301 & 8.36189 & 342.1428 & 375.4891 & 234.72 & 445.03 \\
\hline June & 72 & 392.1426 & 58.77435 & 6.92662 & 378.3313 & 405.9539 & 277.25 & 475.36 \\
\hline Total & 360 & 322.7777 & 94.96072 & 5.00487 & 312.9352 & 332.6203 & 103.26 & 475.36 \\
\hline
\end{tabular}

Table 2: Best single and multiple -regression models were generatedusing enter independent variable selection

\begin{tabular}{llllll}
\hline Model & R Square & Adj-R2 & $\begin{array}{l}\text { Std error } \\
\text { of estimation }\end{array}$ & F & Sig \\
\hline February & .830 & .675 & 35.08583 & 50.067 & 0.001 \\
March & .888 & .779 & 41.78736 & 84.362 & 0.001 \\
April & .816 & .651 & 70.77707 & 45.097 & 0.001 \\
May & .949 & .896 & 22.86610 & 205.207 & 0.001 \\
June & .891 & .784 & 27.30075 & 87.022 & 0.001 \\
\hline
\end{tabular}

Table 3:Logged-over area estimates of the coefficient of the model of environmental parameters in ${ }^{0} \mathrm{C}$ and $\%$ for soiltemperature, soil moisture and water potential in

\begin{tabular}{|c|c|c|c|c|c|c|c|c|}
\hline \multirow{3}{*}{\multicolumn{2}{|c|}{$\overline{\text { Model }}$}} & \multicolumn{7}{|c|}{ February } \\
\hline & & $\begin{array}{l}\text { Unstandardized } \\
\text { Coefficients }\end{array}$ & & $\begin{array}{l}\text { Standardized } \\
\text { Coefficients }\end{array}$ & $\mathrm{t}$ & Sig. & $\begin{array}{l}\text { Collinearity } \\
\text { Statistics }\end{array}$ & \\
\hline & & $\mathrm{B}$ & Std. Error & Beta & & & Tolerance & VIF \\
\hline \multirow{4}{*}{1} & (Constant) & -13627.200 & 2186.751 & & -6.232 & .000 & & \\
\hline & FEBtmp & 185.898 & 39.631 & .447 & 4.691 & .000 & .505 & 1.979 \\
\hline & FEBmt & 149.756 & 59.588 & .204 & 2.513 & .014 & .694 & 1.441 \\
\hline & FEB wp & 51.569 & 7.514 & .561 & 6.863 & .000 & .687 & 1.457 \\
\hline
\end{tabular}

a. Dependent Variable: FEBCO2, FEBtmp= February soil temperature , FEBmt= February soil moisture, FEB $w p=$ February water potential

Table 4: Logged-over area estimates of the coefficient of the model of environmental parameters

\begin{tabular}{|c|c|c|c|c|c|c|c|}
\hline Iodel & $\begin{array}{l}\text { Unstandardized } \\
\text { Coefficients } \\
\text { B }\end{array}$ & Std. Error & $\begin{array}{l}\text { Standardized } \\
\text { Coefficients } \\
\text { Beta }\end{array}$ & $\mathrm{t}$ & Sig. & $\begin{array}{l}\text { Collinearity } \\
\text { Statistics } \\
\text { Tolerance }\end{array}$ & VIF \\
\hline (Constant) & 2652.121 & 3102.810 & & .855 & 396 & & \\
\hline MARtmp & 544.777 & 46.227 & .904 & 11.785 & .000 & .530 & 1.887 \\
\hline MARmt & -435.677 & 30.385 & -1.089 & -14.339 & .000 & .539 & 1.854 \\
\hline MARwp & -61.260 & 37.803 & -.116 & -1.621 & .110 & .611 & 1.636 \\
\hline
\end{tabular}

a. Dependent Variable: MARCO2, MARtmp=March soil temperature, MARmt=march soil moisture, MARwp=March water potential

Table 5: Logged-over area estimates of the coefficient of the model of environmental parameters in ${ }^{0} \mathrm{C}$ and $\%$ forsoil temperature, soil moisture and water potential in April.

\begin{tabular}{|c|c|c|c|c|c|c|c|c|}
\hline \multicolumn{2}{|c|}{ Model } & $\begin{array}{l}\text { Unstandardized } \\
\text { Coefficients } \\
\text { B }\end{array}$ & Std. Error & $\begin{array}{l}\text { Standardized } \\
\text { Coefficients } \\
\text { Beta }\end{array}$ & $\mathrm{t}$ & Sig. & \multicolumn{2}{|l|}{$\begin{array}{l}\text { Collinearity } \\
\text { Statistics }\end{array}$} \\
\hline \multirow{4}{*}{1} & (Constant) & -159697.710 & 50947.962 & & -3.135 & .003 & & \\
\hline & APLtmp & 170.193 & 48.721 & .546 & 3.493 & .001 & .201 & 4.974 \\
\hline & APLmt & -210.401 & 122.185 & -.381 & -1.722 & .090 & .101 & 9.940 \\
\hline & APLwp & 1659.239 & 490.792 & .895 & 3.381 & .001 & .070 & 14.243 \\
\hline
\end{tabular}


Table 6: Logged-over area estimates of the coefficient of the model of environmentalparameters in ${ }^{0} \mathrm{C}$ and $\%$ forsoil temperature, soil moisture and water potential in May

\begin{tabular}{|c|c|c|c|c|c|c|c|}
\hline Model & $\begin{array}{l}\text { Unstandardized } \\
\text { Coefficients } \\
\text { B }\end{array}$ & Std. Error & $\begin{array}{l}\text { Standardized } \\
\text { Coefficients } \\
\text { Beta }\end{array}$ & $\mathrm{T}$ & Sig. & $\begin{array}{l}\text { Collinearity } \\
\text { Statistics } \\
\text { Tolerance }\end{array}$ & VIF \\
\hline (Constant) & -50245.705 & 7821.863 & & -6.424 & .000 & & \\
\hline MAYtmp & 8.392 & 5.031 & .077 & 1.668 & .100 & .678 & 1.474 \\
\hline${ }^{1}$ MAYmt & -163.808 & 20.183 & -.513 & -8.116 & .000 & .366 & 2.732 \\
\hline MAYwp & 562.946 & 77.108 & .492 & 7.301 & .000 & .322 & 3.107 \\
\hline
\end{tabular}

moisture, MAYwp= May water potential

Table 7: Logged-over area estimates of the coefficient of the model of environmental parameters in ${ }^{0} \mathrm{C}$ and $\%$ for soil temperature, soil moisture and water potential in June.

\begin{tabular}{|c|c|c|c|c|c|c|c|}
\hline \multirow[t]{2}{*}{ Model } & \multicolumn{2}{|c|}{$\begin{array}{l}\text { Unstandardized } \\
\text { Coefficients }\end{array}$} & \multirow{2}{*}{$\begin{array}{l}\text { Standardized } \\
\text { Coefficients } \\
\text { Beta }\end{array}$} & \multirow[t]{2}{*}{$\mathrm{t}$} & \multirow[t]{2}{*}{ Sig. } & \multicolumn{2}{|c|}{$\begin{array}{l}\text { Collinearity } \\
\text { Statistics }\end{array}$} \\
\hline & B & Std. Error & & & & Tolerance & VIF \\
\hline (Constant) & 96.487 & 1444.078 & & .067 & .947 & & \\
\hline JUNtmp & 91.737 & 8.705 & .608 & 10.538 & .000 & .913 & 1.095 \\
\hline IUNmt & -83.869 & 9.742 & -.497 & -8.609 & .000 & .913 & 1.095 \\
\hline JUNwp & 4.608 & 14.136 & .018 & .326 & .745 & .999 & 1.001 \\
\hline
\end{tabular}

a. Dependent Variable: JUNCO2, JUNtmp=June soil temperature, JUNmt=June soil moisture, JUNwp=June water potential

Table 8: Analysis of soil samples

\begin{tabular}{|l|l|l|l|l|l|l|}
\hline ECOSYSTEM & $\begin{array}{l}\text { SOC } \\
\%\end{array}$ & TOC & $\mathrm{pH}$ & $\begin{array}{l}\text { Soil } \\
\text { Moisture } \\
\text { Content } \%\end{array}$ & $\begin{array}{l}\text { Moisture } \\
\text { Correction } \\
\text { factor }\end{array}$ & SOCstockMg/ha \\
\hline Logged Area & 2.12 & 1.4 & 5.75 & 15.47 & 1.15 & 23.32 \\
\hline
\end{tabular}

TOC $=$ Total Organic Carbon, SOC=Soil Organic Carbon, SOCstock=Soil Organic Carbon stock

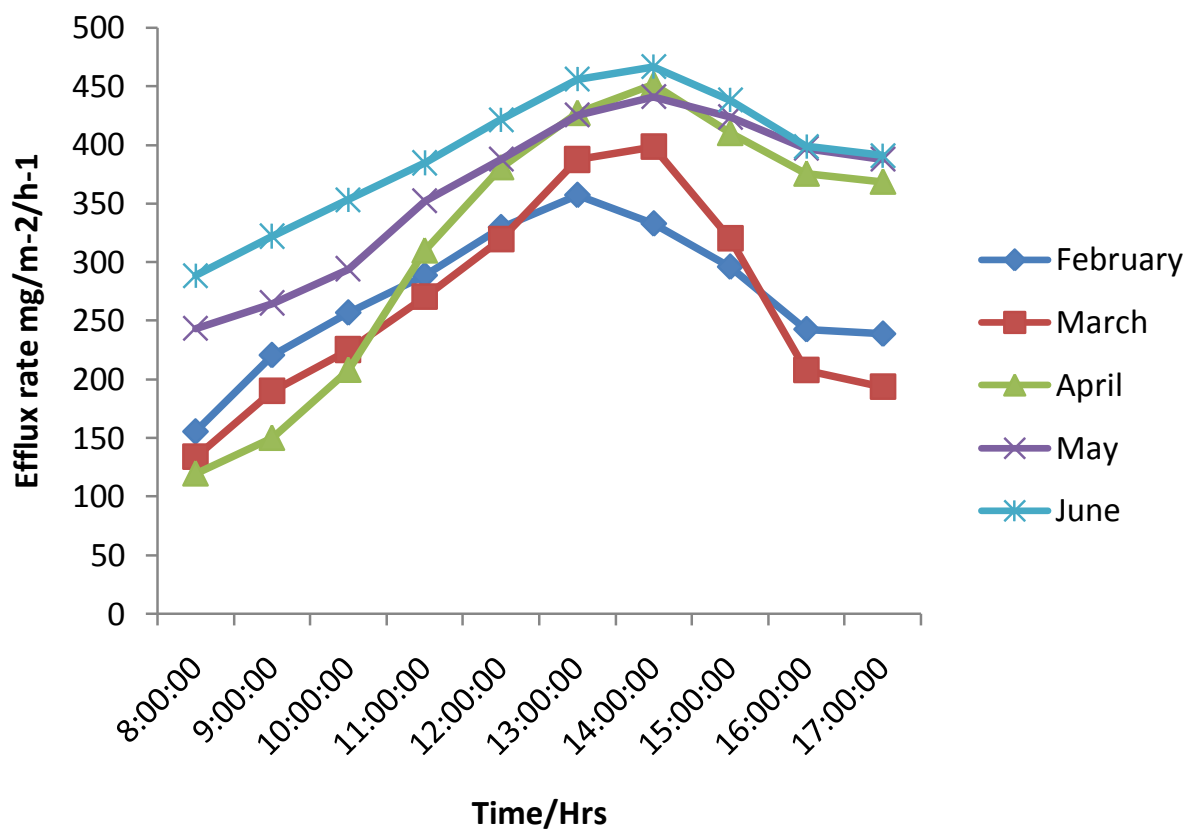

Fig. 1. Monthly Soil $\mathrm{CO}_{2}$ efflux trend 


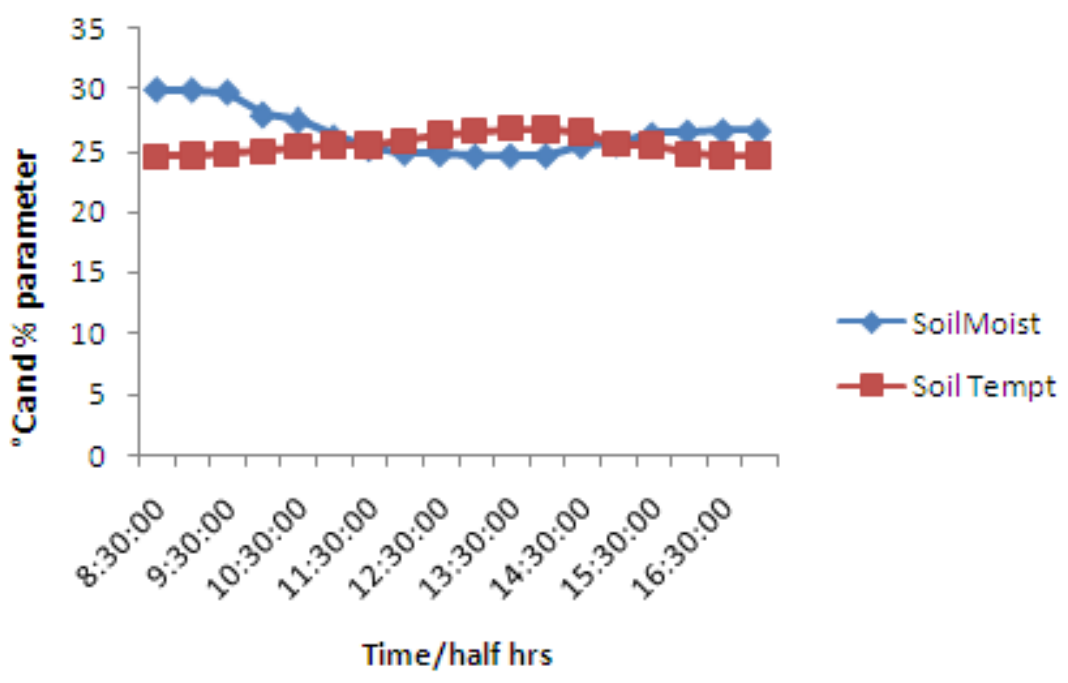

Fig. 2. Average Soil temperature and moisture

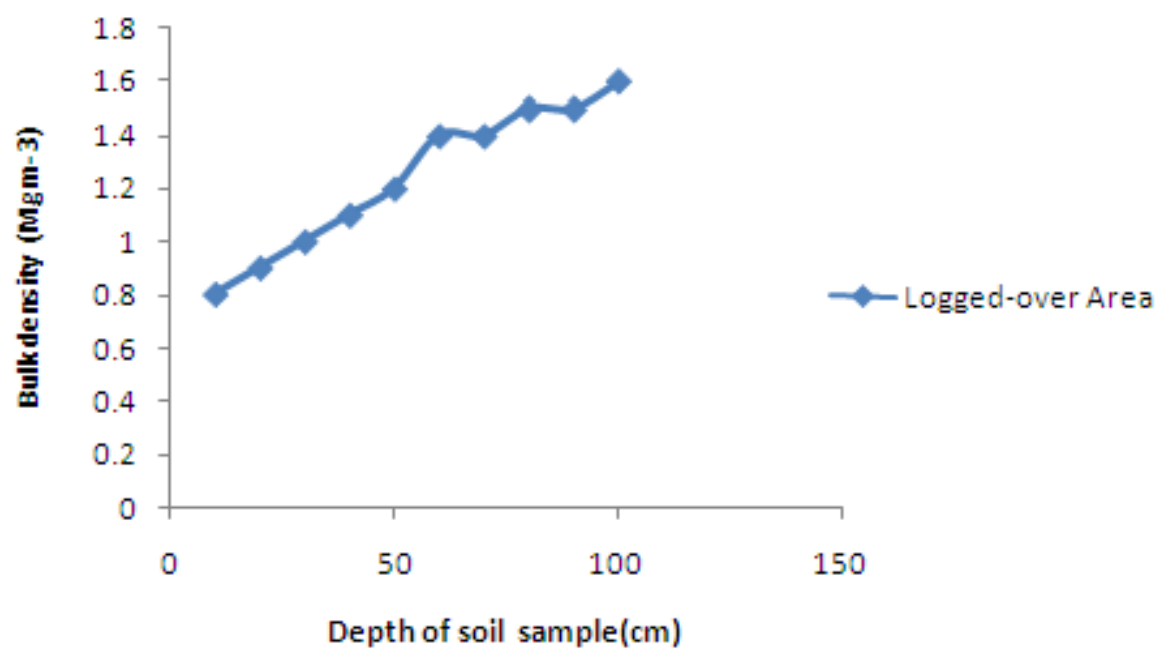

Fig. 3. Earth Bulk Density

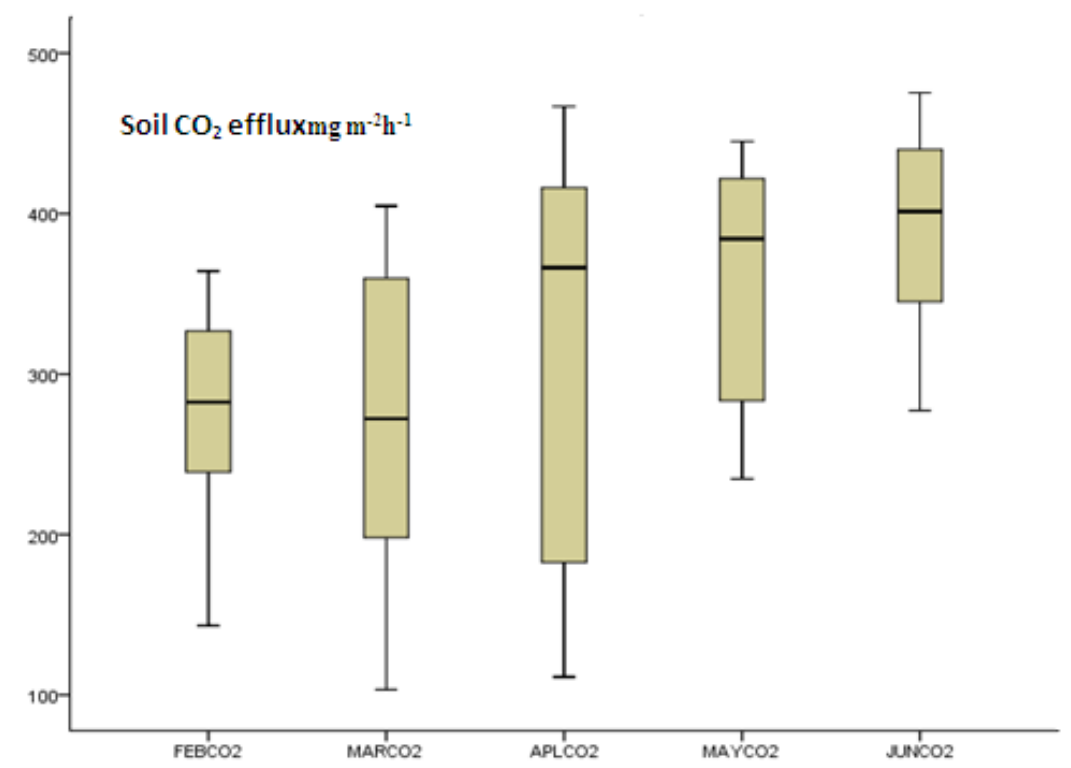

$\mathrm{m}$

Fig. 4.Box and whisker plot of Soil $\mathrm{CO}_{2}$ efflux 